\title{
TEKNIS PRODUKSI PEMBENIHAN DAN PENDEDERAN IKAN LEMON ALGAE EATER Gyrinocheilus aymonieri (Tirant, 1884) DI ADE'S FISH FARM, KABUPATEN BOGOR, JAWA BARAT
}

\author{
(Lemon Algae Eater Gyrinocheilus aymonieri (Tirant, 1884) Hatchery and \\ Nursery Techniques in Ade's Fish Farm, Bogor Regency, West Java)
}

Cecilia Eny Indriastuti' ${ }^{1}$, M. Ramadhani Prigunawan')

1) Program Studi Teknologi Produksi dan Manajemen Perikanan Budidaya, Sekolah Vokasi, Institut Pertanian Bogor, Bogor

Email : cecilia_eny@apps.ipb.ac.id

\begin{abstract}
Lemon fish algae eater is one of the ornamental fish which is well-known as algae eater. The lemon algae eater is placed in a pond measuring $2 \mathrm{~m} \times 3 \mathrm{~m} \times 0.8 \mathrm{~m}$, with a water height of $50 \mathrm{~cm}$. For optimum health, feed the algae eater with Feng Li pellets by having a restricted feeding method or this can also be limited to $5 \%$ from the brood fish weight. The semi-natural hatchery of lemon fish algae eater is needed. An aquarium $(100 \mathrm{~cm} \times 60 \mathrm{~cm} x$ $50 \mathrm{~cm}$ ) with a water height of $30 \mathrm{~cm}$ is needed for the hatchery of lemon fish algae eater eggs. The average fecundity of lemon fish algae eater eggs produced in 1 spawning can reache up to 84742 eggs with the average of fertilization rate is $79 \%$, the hatching rate is $83 \%$, and the survival rate is $74 \%$. The lemon algae eater eggs will hatch in 10-12 hours. Fish nursery of lemon fish algae eater has used pond measures $3 m \times 2 m \times 1.5 \mathrm{~m}$. The freshly hatched larvae are harvested at the age of 30 days and 45 days with a size of 1.2$1.5 \mathrm{~cm} /$ fish and $2.5-3 \mathrm{~cm} /$ fish.
\end{abstract}

Key words : Lemon fish algae eater, hatchery, and nursery 


\section{PENDAHULUAN}

Negara Indonesia memiliki prospek yang baik pada komoditas ikan hias dan mendapat banyak keuntungan karena permintaan pasar ikan hias yang tinggi (Tarwiyah 2001). Pada saat pandemi Covid-19 permintaan ikan hias semakin meningkat baik pemasaran dalam negeri ataupun untuk kebutuhan ekspor. Hal ini semakin menarik minat masyarakat untuk memulai usaha budidaya ikan hias Usaha ikan hias juga dapat meningkatkan perekonomian pada saat banyak tenaga kerja yang kehilangan pekerjaan pada situasi saat ini (DJBP, 2021), dan dapat menjadi program pengentasan kemiskinan seperti program APP (Anti Poverty Programme) yang dilakukan di Kecamatan Wajak, Kabupaten Malang, Jawa Timur (Oktariza, 2017).

Salah satu ikan hias yang diminati adalah chinese algae eater atau biasa disebut CAE atau lemon algae eater. Ikan ini merupakan salah satu ikan akuarium yang dikenal sebagai pemakan alga. Ikan tersebut dideskripsi oleh Tirant pada tahun 1884 (Fricke et.al. 2021; Kottelat, 2013). Ikan lemon algae eater ditemukan alami di perairan negara Asia Tenggara yaitu Kamboja, Laos, Malaysia, Myanmar, Thailand, dan Vietnam (Vidthayanon, 2012), dan dimanfaatkan sebagai ikan hias dan konsumsi. Ikan tersebut memiliki mulut yang berfungsi untuk melekat pada benda di dasar sungai sehingga disebut suckermouth. Data produksi ikan lemon algae eater meningkat di pasar ikan hias setiap tahunnya. Tahun 2016 data produksi ikan lemon alga eater di pasar ikan hias mencapai 310000 ekor, dan pada tahun 2017 mencapai 336000 ekor (KKP, 2017).

Ade's Fish Farm yang berlokasi di Ciherang Hegarsari, Kecamatan Dramaga, Kabupaten Bogor, Jawa Barat merupakan salah satu pembudidaya ikan hias yang cukup besar yang mempunyai fasilitas yang sangat baik untuk menunjang kegiatan budidaya ikan hias. Beberapa jenis ikan hias sudah banyak dibudidayakan di Ade's Fish Farm. Diantaranya ikan hias yang intensif dikembangkan yaitu ikan lemon algae eater. Dikarenakan permintaan ikan lemon algae eater setiap tahun meningkat maka perlu dipelajari lebih lanjut aspek teknis produksi pembenihan dan pendederan ikan lemon algae eater di Ade's Fish Farm.

\section{METODE PENELITIAN}

Penelitian dilaksanakan pada tanggal 6 Januari hingga 8 April 2020. Lokasi yang dipilih adalah Ade's Fish Farm, yang beralamat di Ciherang Hegarsari RT 05/RW 08 Desa Ciherang, Kecamatan Dramaga, Kabupaten Bogor, Jawa Barat. Peta alamat Ade's Fish Farm disajikan pada Gambar 1.

Metode yang dilakukan dalam kegiatan ini adalah melaksanakan secara langsung seluruh kegiatan pembenihan dan pendederan mencakup pemeliharaan induk, pengamatan induk yang matang gonad, pemijahan, penetasan telur, pemeliharaan larva, pemantauan kualitas air sampai pemanenan. Selain mengikuti secara langsung seluruh aktifitas, juga dilakukan pengamatan, wawancara dan pencatatan, serta mengumpulkan dan membandingkan informasi-informasi sejenis atau studi pustaka dengan hasil wawancara dan observasi yang dilakukan. Informasi yang diperbandingkan antara lain: cara pengobatan ikan, baku mutu air, jumlah pakan dan dosis hormon yang diberikan. 


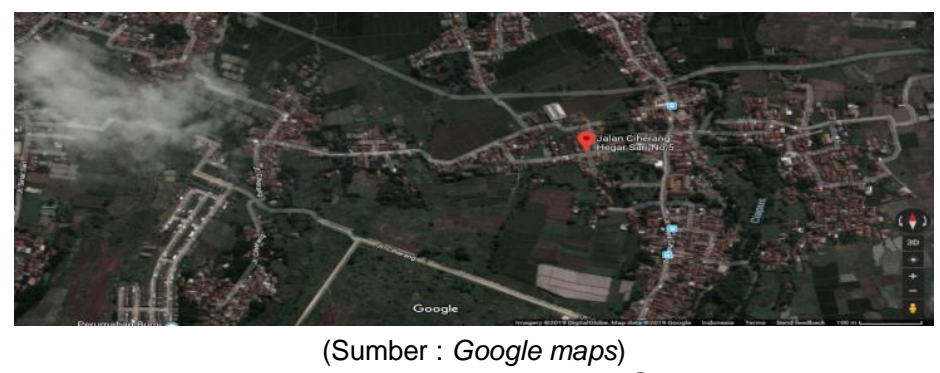

Gambar 1 Peta lokasi Ade's Fish Farm. Jalan Hegar Sari RT 5 RW 8, Desa Ciherang, Kecamatan Dramaga. Kabupaten Bogor, Jawa Barat

\section{HASIL DAN PEMBAHASAN}

\section{Kegiatan Pembenihan}

Kegiatan pembenihan adalah kegiatan awal dalam melakukan budidaya. Tanpa pembenihan, kegiatan pendederan tidak akan terlaksana, karena benih yang digunakan pada pendederan semuanya berasal dari kegiatan pembenihan. Secara garis besar, kegiatan pembenihan meliputi pemilihan induk, pemijahaan induk, penetasan telur, pemeliharaan larva, dan pemeliharaan benih (Khairuman dan Amri, 2002).

\subsection{Pemeliharaan Induk Ikan Lemon Algae Eater Gyrinocheilus aymonieri}

Induk ikan lemon algae eater yang terdapat di Ade's Fish Farm berasal dari pembudidaya yang berada di wilayah Bogor. Induk lemon algae eater dibeli pada saat ikan tersebut berukuran $8-10 \mathrm{~cm} /$ ekor. Induk lemon algae eater dipelihara terlebih dahulu selama tiga bulan untuk penyesuaian lingkungan dan pematangan gonad. Ciri-ciri jantan dan betina pada induk ikan lemon algae eater yaitu pada jantan memiliki ukuran tubuh ramping, pada sirip pectoral lancip, dan bila di striping mengeluarkan sperma. Sedangkan pada induk betina memiliki ukuran tubuh bulat, pada sirip pectoral tidak lancip, dan bila menggunakan alat kateter mengeluarkan telur (Gambar 2). Jumlah induk yang terdapat di Ade's Fish Farm berjumlah 800 ekor yang terdiri 400 betina dan 400 jantan.

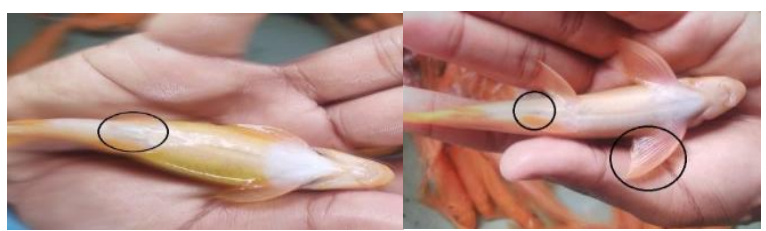

(a)

(b)

Gambar 2 Perbedaan Induk : (a) Betina, b) Jantan

\subsection{Persiapan Wadah Induk}

Wadah pemeliharaan induk ikan lemon algae eater menggunakan bak beton yang berukuran $2 \mathrm{~m}$ x $3 \mathrm{~m}$ x 0,8 m (Gambar 3). Persiapan wadah dilakukan dengan cara menggosok dinding pada bak beton dan setelah itu dilakukan pengeringan 
selama 30 menit. Bak beton kemudian diisi air dengan tinggi $50 \mathrm{~cm}$ dan pasangkan aerasi. Jumlah wadah induk lemon algae eater berjumlah 4 kolam.

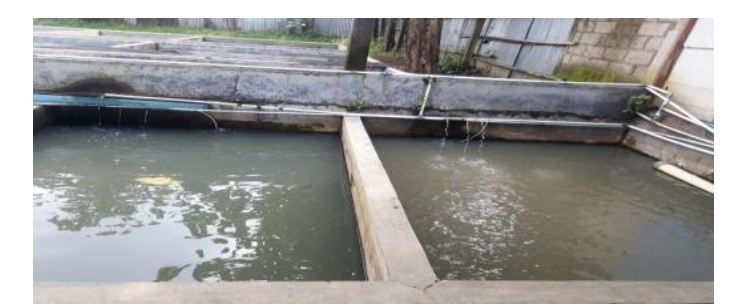

Gambar 3 Wadah induk ikan lemon algae eater

\subsection{Penebaran Induk}

Penebaran induk dilakukan dengan cara memisahkan antara induk jantan dan betina, hal ini bertujuan untuk memudahkan pada saat penyeleksian induk (Gambar 4). Induk jantan dan betina yang telah dipisahkan, kemudian ditebar dengan padat tebar $200 \mathrm{ekor} / \mathrm{m}^{2}$.

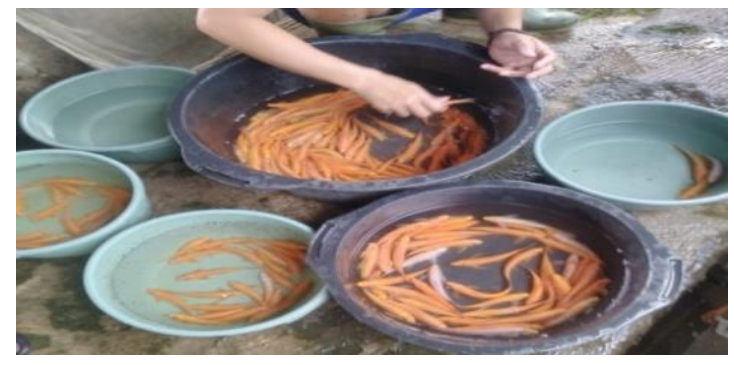

Gambar 4 Seleksi induk

\subsection{Pemberian Pakan}

Menurut Nainggolan (2014), nutrisi untuk induk baik kualitas maupun kuantitas akan mampu memperbaiki performa reproduksi, mempercepat proses pematangan gonad, serta meningkatkan hasil reproduksi. Pemberian pakan pada induk adalah hal yang penting karena pakan yang diberikan merupakan materi pembentuk telur atau sperma ikan. Pemberian pakan yang berlebih, selain banyak pakan yang tidak termakan juga akan merusak kualitas air yang akan mengganggu kesehatan ikan. Sebaliknya jika induk kekurangan pakan maka induk akan mengadaptasikan diri dengan mengurangi fekunditas dan daya tetas telur (Nikolsky dalam Tang dan Affandi, 2000). Pemberian pakan pada induk lemon algae eater dilakukan sebanyak 2 kali dalam satu hari yaitu, pagi hari pukul 09.00 dan sore hari pukul 16.00 WIB.

Pakan yang diberikan menggunakan pelet Feng Li (Gambar 5). Penggunaan pakan pelet Feng Li dikarena mempunyai kandungan protein yang tinggi tetapi rendah lemak dan dapat meningkatkan kematangan gonad pada induk lemon algae eater. Pemberian pakan dilakukan dengan cara restricted atau dengan metode pemberian pakan dibatasi, karena pada induk pakan yang diberikan ditujukan hanya untuk perkembangan gonad bukan untuk pertumbuhan somatik. Banyaknya pemberian pakan dibatasi dengan menggunakan $5 \%$ dari bobot induk. 
Pakan yang dihabiskan dalam satu kali pemberian pakan yaitu $300 \mathrm{~g} / \mathrm{kolam}$ induk. Kualitas sperma dan telur pada induk sangat dipengaruhi oleh kandungan nutrisi dari pakan yang diberikan (Memis dan Gun, 2004). Dengan demikian sangat penting untuk memperhatikan formulasi pakan yang akan diberikan kepada induk. Selama masa pemeliharaan, induk diberi pakan pelet dengan kandungan protein antara $28-30 \%$ dan lemak sekitar 7\%.

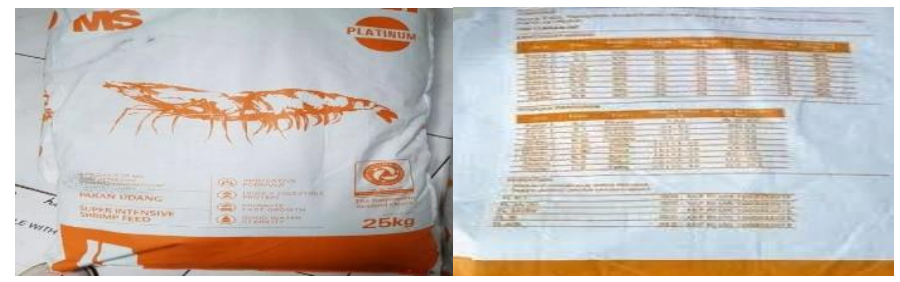

(a)

(b)

Gambar 5 Pakan : (a) Pellet Feng Li, (b) Kandungan pelet Feng Li

\subsection{Pengelolaan Kualitas Air}

Kualitas air yang baik akan mempengaruhi kesehatan induk dan kemauan induk memijah, apabila kualitas air memburuk akan mengakibatkan ikan stres dan menurunkan tingkat kematang gonad pada induk. Penurunan kualitas air didalam kolam induk ditandai dengan perubahan warna pada kolam yang sebelumnya bening menjadi keruh dan banyaknya ikan yang berkumpul pada saluran inlet. Pada pengelolahan kualitas air di wadah pemeliharaan induk, dilakukan menggunakan cara sistem flowtrough yaitu sistem air mengalir secara perlahan yang berasal dari sungai irigasi. Kualitas air yang diukur yaitu $\mathrm{pH}$, suhu, dan amonia. Untuk monitoring saluran air dilakukan dua kali dalam seminggu dengan cara melihat, apakah ada sampah yang menyumbat di saluran inlet. Waktu pengukuran kualitas air yaitu pagi jam 07.00 , siang jam 13.00, dan sore hari jam 16.00 , pengukuran kualitas air diukur pada bagian pertengahan kolam. Data hasil pengukuran kualitas air pada keseluruhan kolam induk ikan lemon algae eater dapat dilihat pada Tabel 1.

Tabel 1 Data Kualitas Air Pada Induk Lemon Algae Eater

\begin{tabular}{ccc}
\hline Parameter & $\begin{array}{c}\text { Pengukuran Kualitas } \\
\text { Air }\end{array}$ & $\begin{array}{c}\text { Kualitas air di alam } \\
\text { (Kusrini dan Priono 2011) }\end{array}$ \\
\hline Suhu & $27^{\circ} \mathrm{C}-30^{\circ} \mathrm{C}$ & $26{ }^{\circ} \mathrm{C}-31^{\circ} \mathrm{C}$ \\
$\mathrm{pH}$ & $6.5-7$ & $5-6,5$ \\
Amonia & $1,5 \mathrm{mg} / \mathrm{L}$ & Maksimal $3 \mathrm{mg} / \mathrm{L}$ \\
\hline
\end{tabular}

\subsection{Pencegahan Hama dan Penyakit}

Pada wadah pemeliharaan induk ikan lemon algae eater terkadang mengalami kendala, yaitu induk terserang penyakit. Penyakit yang biasa menyerang induk lemon algae eater yaitu finrot. Ciri-ciri induk ikan lemon algae eater yang terkena penyakit finroot, yaitu pada bagian sirip terdapat luka dan apabila sudah parah, ikan tersebut akan sulit untuk berenang. Pencegahan penyakit tersebut dilakukan dengan cara pergantian air $50 \%$ dalam waktu seminggu sekali dan jika ikan tersebut sudah terkena penyakit finrot, maka 
dilakukan pengobatan dengan cara mengambil beberapa ikan yang terkena penyakit tersebut kemudian dipelihara dalam wadah akuarium ukuran $150 \mathrm{~cm}$ x 60 $\mathrm{cm} \times 50 \mathrm{~cm}$ dengan tinggi air $30 \mathrm{~cm}$ lalu diberikan obat furazolidone dengan dosis $2 \mathrm{~mL} / \mathrm{L}$.

\subsection{Pemijahan Induk}

Pemijahan induk ikan lemon algae eater dilakukan dengan cara semi alami dengan perbandingan sex ratio yaitu 3 jantan : 1 betina, induk yang dipijahkan merupakan induk dipelihara sendiri dan hasil seleksi dari stok induk. Pemijahan yang dilakukan sebanyak sekali sebulan (empat kali selama pengamatan) karena keterbatasan akuarium.

\subsection{Persiapan Wadah Pemijahan Induk}

Aktifitas pemijahan induk ikan lemon algae eater menggunakan wadah akuarium ukuran $150 \mathrm{~cm} \times 60 \mathrm{~cm} \times 50 \mathrm{~cm}$ dengan tinggi air $30 \mathrm{~cm}$, sebanyak 2 unit. Persiapan wadah yang pertama kali dilakukan dengan cara menggosok dinding akuarium menggunakan busa dan kanebo, kemudian dilakukan pengeringan selama satu hari. Wadah yang sudah dikeringkan kemudian diisi air dengan tinggi air $30 \mathrm{~cm}$ dan diberi dua titik aerasi (Gambar 6). Persiapan wadah harus dilakukan karena wadah pemijahan harus steril agar selama proses pemijahan tidak terjadi kendala.

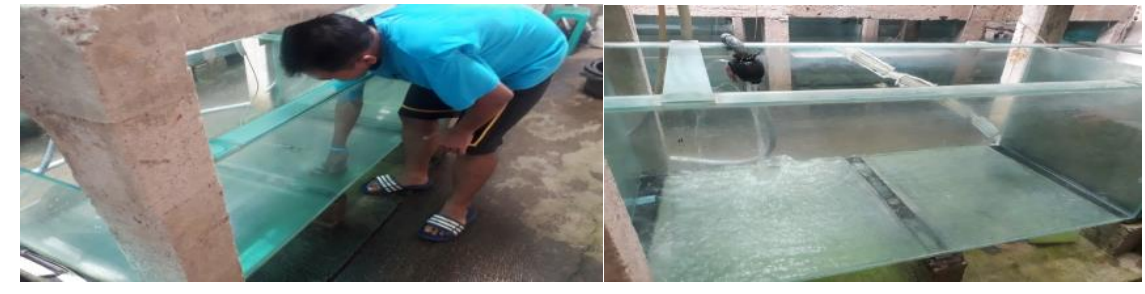

(a) (b)

Gambar 6 Persiapan Wadah Pemijahan Induk : (a) Persiapan wadah, (b) Pengisian air

\subsection{Seleksi Induk}

Seleksi induk ikan lemon algae eater bertujuan untuk mengetahui kematangan gonadnya (Gambar 7). Pada induk ikan lemon algae eater untuk mengetahui jantan dan betina yang siap dipijahkan dapat dilihat secara visual. Ciriciri induk jantan yang sudah matang gonad berumur 1 tahun dengan ukuran \pm 10 $\mathrm{cm}$, memiliki tubuh ramping, perut tipis dan apabila distripping mengeluarkan sperma. Sedangkan ciri-ciri induk betina yang sudah matang gonad berumur 1,2 tahun dengan ukuran panjang tubuh $\pm 10 \mathrm{~cm}$, memiliki perut buncit dan apabila distripping mengeluarkan telur. 


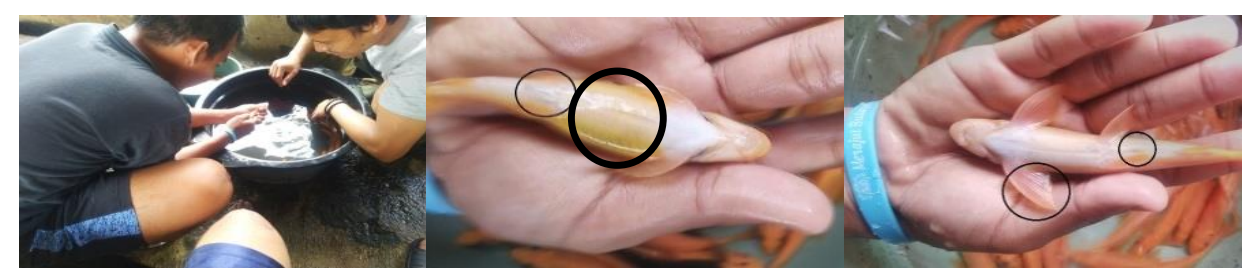

(a)

(b)

(c)

Gambar 7 (a) Seleksi induk, (b) Induk betina matang gonad, (c) Induk jantan matang gonad

\subsection{Stimulasi Pemijahan}

Teknik pemijahan yang digunakan dalam pemijahan ikan lemon algae eater menggunakan pemijahan secara semi alami. Sex ratio induk yang dipijah yaitu 3 $\delta: 1$. Penentuan sex rasio didasarkan dari pengalaman empiris pembudidaya. Aktifitas pemijahan yang dilakukan membutuhkan 60 induk jantan dan 20 induk betina. Untuk menstimulasi pemijahan digunakan hormone dengan merk dagang ovaprim. Ovaprim mengandung gonadotropin hormon (GtH) yang dapat mempercepat proses sintesa hormon 17a-hidroksiprogesteron menjadi 17a, 20ßdihidroksiprogesteron yang berfungsi sebagai steroid yang merangsang pematangan gonad dan mempercepat proses integrasi inti sel telur menuju posisi germinal vesicle breakdowan (GVBD; Suriansyah et al. 2010). Dosis penyuntikan menggunakan dosis ovaprim $0,5 \mathrm{~mL} / \mathrm{Kg}$ untuk induk betina dan 0,3 $\mathrm{mL} / \mathrm{Kg}$ untuk induk jantan, hal ini sesuai dengan penelitian yang dilakukan Suriansyah et al 2010 pada ikan betok Anabas testudineus yang menggunakan dosis $0,5 \mathrm{~mL} / \mathrm{Kg}$ bobot ikan dapat memperbaiki perkembangan gonad yang ditunjukkan dengan peningkatan nilai gonado somatik indeks (GSI) sebanyak $2,72 \%$, peningkatan diameter telur menjadi $0,77 \mathrm{~mm}(71,50 \%)$ dan mempercepat waktu ovulasi menjadi 4 sampai 3 jam. Ovaprim yang digunakan diencerkan dengan $\mathrm{NaCl}$ dengan perbandingan 1:2. Penyuntikan dilakukan 1 kali pada pukul 16.00 WIB. (Gambar 8). Sebelum induk ikan lemon algae eater dipijahkan, induk ditimbang dahulu yang bertujuan untuk menentukan jumlah ovaprim yang disuntikkan, kemudian dilakukan anastesi menggunakan minyak cengkeh dengan dosis $0,002 \mathrm{~mL} / \mathrm{L}$.

Pembiusan berlangsung sampai ikan terlihat lemas dan tidak bergerak, waktu pembiusan membutuhkan waktu sekitar 10 detik. Penyuntikan dilakukan pada bagian intramuscular atau dibagian punggung ikan. Jarum suntik yang berisikan hormon disuntikkan pada bagian punggung tubuh lemon algae eater dengan sudut kemiringan $45^{\circ}$. Kemudian induk jantan dan betina ditebar pada akuarium pemijahan. Proses pemijahan berlangsung pada malam hari, lebih baiknya jam 21.00 WIB atau 5 jam setelah penyuntikan. Setelah terjadi pemijahan, induk lemon algae eater diangkat dan dipindahkan ke dalam bak pemeliharaan induk. 


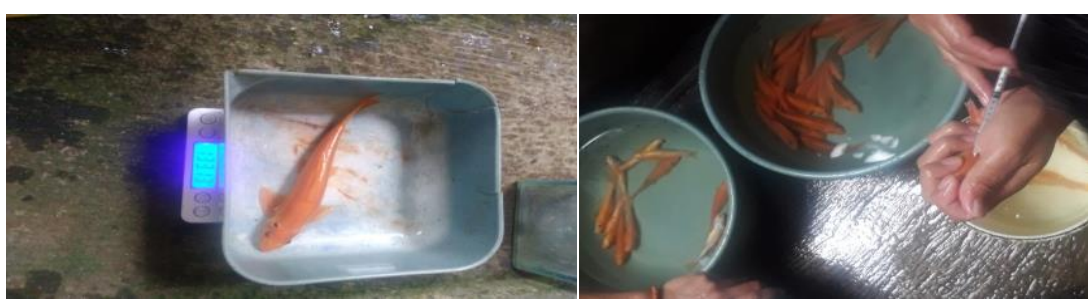

(a)

(b)

Gambar 8 Stimulasi Pemijahan : (a) Penimbangan induk, (b) Proses penyuntikan indukan

\subsection{Wadah Penetasan telur}

Wadah yang digunakan untuk inkubasi telur menggunakan akuarium ukuran $100 \mathrm{~cm} \times 50 \mathrm{~cm} \times 50 \mathrm{~cm}$ sebanyak 40 unit. Kegiatan persiapan wadah yang pertama kali dilakukan dengan cara menggosok dinding akuarium menggunakan busa dan kanebo, kemudian dilakukan pengeringan selama satu hari. Wadah yang sudah dikeringkan kemudian diisi air dengan tinggi air $30 \mathrm{~cm}$ dan diberi 2 titik aerasi (Gambar 9).

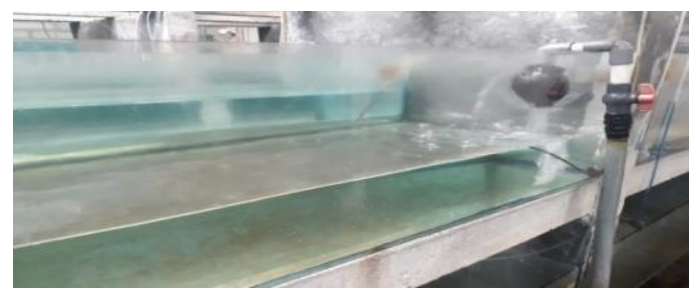

Gambar 9 Pengisian air wadah inkubasi telur

\subsection{Penebaran Telur}

Setelah induk dipijahkan, induk dipindahkan ke dalam bak induk dan telur ikan lemon algae eater diserok menggunakan serokan sedang ukuran $45 \mathrm{~cm} \times 30$ $\mathrm{cm}$. Perhitungan telur ikan lemon algae eater dilakukan dengan cara menghitung sampel telur seberat 0,1 gram sebanyak tiga kali pengulangan. Kemudian telur ditebar pada wadah inkubasi telur yang sudah disiapkan, dengan padat tebar 5 000 butir telur/akuarium Setelah itu wadah inkubasi telur diberi MB (Methylene blue) dengan dosis $2 \mathrm{~mL} / \mathrm{L}$ dan diberi dua titik aerasi. Menurut Fanitalya (2012), salah satu upaya dalam pencegahan dan penanganan telur ikan yang terserang jamur yaitu dengan cara menambahkan bahan kimia yang bertujuan untuk menghambat pertumbuhan jamur. Beberapa bahan kimia yang sering digunakan untuk mencegah dan mengobati serangan jamur pada telur ikan seperti Methylene blue, Melatchite green, dan Kalium permanganate (PK).

Telur lemon algae eater akan menetas apabila dalam keadaan melayang dan teraduk, maka dilakukan pemberian dua titik aerasi yang bertujuan agar telur terus teraduk (Gambar 10). Telur ikan lemon algae eater akan menetas dalam waktu $10-12$ jam. Fekunditas telur yang dihasilkan pada satu siklus pemijahan dapat diperoleh dari hasil pengurangan bobot awal induk sebelum memijah yang dikurangi dengan bobot induk setelah memijah. Hasil derajat penetasan telur dapat diketahui dengan cara mengambil sampel telur sebanyak 100 butir telur yang di inkubasi pada akuarium berukuran $30 \mathrm{~cm} \times 10 \mathrm{~cm} \times 20 \mathrm{~cm}$ dengan tiga kali 
pengulangan. Setelah enam jam dapat dilihat perbedaan telur yang dibuahi dan tidak dibuahi. Menurut Wijayanti dan Simanjuntak (2006) perbedaan telur yang dibuahi akan terlihat bening sedangkankan telur yang tidak dibuahi akan berubah warna menjadi putih susu.

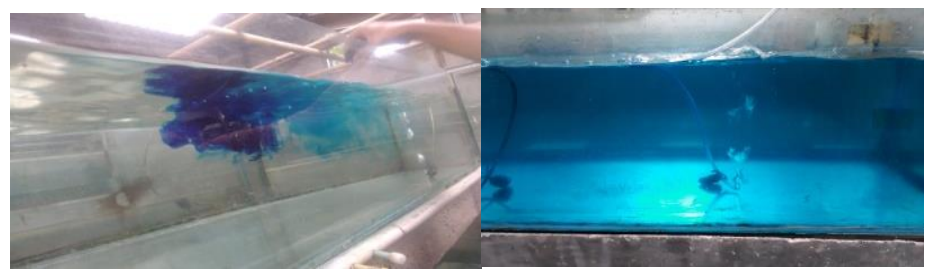

(a)

(b)

Gambar 10 (a) Pemberian Metylene Blue (MB) , (b) Wadah inkubasi telur

Setelah dilakukan pengamatan, rata-rata persentase telur yang dibuahi, Fertilitation Rate (FR) yaitu $79 \%$ dari total telur yang dihasilkan, sedangkan ratarata persentase telur yang menetas, Hatching Rate (HR) mencapai $83 \%$ dari total telur yang dibuahi, untuk tingkat kelangsungan hidup, Survival Rate (SR) pada larva sebesar $74 \%$. Hasil 4 kali pemijahan ikan lemon algae eater didapatkan jumlah telur rata-rata yang dihasilkan sebanyak 95958 butir telur (Tabel 2).

Tabel 2 Produktivitas telur ikan lemon algae eater

\begin{tabular}{ccccccccc}
\hline Induk & Tanggal & Telur & $\begin{array}{c}\text { FR } \\
(\%)\end{array}$ & $\begin{array}{c}\text { Telur } \\
\text { Terbuahi }\end{array}$ & $\begin{array}{c}\text { HR } \\
(\%)\end{array}$ & $\begin{array}{c}\text { Jumlah } \\
\text { Larva }\end{array}$ & $\begin{array}{c}\text { SR } \\
(\%)\end{array}$ & $\begin{array}{c}\text { Jumlah } \\
\text { Benih }\end{array}$ \\
\hline Pemijahan 1 & $14 / 1 / 2020$ & 96120 & 75 & 72090 & 85 & 61276 & 75 & 45957 \\
Pemijahan 2 & $16 / 1 / 2020$ & 95040 & 80 & 76032 & 83 & 63106 & 70 & 44174 \\
Pemijahan 3 & $28 / 2 / 2020$ & 95472 & 80 & 76377 & 80 & 61102 & 75 & 45826 \\
Pemijahan 4 & $02 / 3 / 2020$ & 97200 & 80 & 77760 & 83 & 64540 & 75 & 48405 \\
\hline & Jumlah & 383832 & & 302260 & & 250026 & 184364 \\
\cline { 2 - 8 } & Rata-rata & 95958 & 79 & 75565 & 83 & 62506 & 74 & 46091 \\
\hline
\end{tabular}

\subsection{Pemeliharaan Larva}

Pemeliharaan larva merupakan aktifitas budidaya yang paling menentukan keberhasilannya untuk kegiatan selanjutnya telur ikan lemon algae eater akan menetas menjadi larva setelah 10-12 jam. Pemeliharaan larva dimulai dari larva sudah bisa berenang dan mencari makan atau yolk egg pada larva telah habis.

\subsection{Pemberian Pakan Larva}

Pemberian pakan larva dilakukan pada hari ke-4 atau ke-5, setelah masa yolk egg pada larva habis. Aktifitas ini dilakukan dengan cara metode at-satiation atau pemberian pakan sekenyang-kenyangnya, sebanyak 3 kali dalam sehari. 
Pemberian pakan dilakukan pada pagi hari pukul 08.00 , siang hari pukul 13.00, dan pada sore hari pukul 16.00 WIB. Pada hari ke-5 atau masa yolk egg habis, larva ikan lemon algae eater diberikan kuning telur matang yang sudah dilarutkan. Menurut Khairuman (2003), menyatakan bahwa pemberian pakan tambahan jenis lain yang dapat diberikan untuk larva adalah dedak halus dan kuning telur, selain itu, pakan tambahan berupa kuning telur yang sifatnya tidak bergerak juga mudah dimakan oleh larva terutama bagi larva yang pergerakannya lambat/kurang aktif, sehingga dapat langsung dimakan oleh larva tanpa banyak mengeluarkan sisa sebagai kotoran.

Telur yang dihabiskan pada pemberian pakan menghabiskan 230 butir telur. Pemberian pakan menggunakan kuning telur diberikan dari larva sampai hari ke18 atau benih siap jual yang berukuran 1-1,2 cm (Gambar 11 a). Pada hari ke-16, dilakukan overlapping pakan berupa pelet Feng Li (Gambar 11 b).

Pemberian pakan menggunakan pelet Feng Li dalam satu akuarium menghabiskan 5 gram dan dalam sehari dapat menghabiskan 15 gram. Dalam pembenihan intensif biasanya diutamakan pemberian pakan buatan. Pakan yang berkualitas baik mengandung zat-zat makanan yang cukup,yaitu protein yang mengandung asam amino esensial, karbohidrat, lemak, vitamin, dan mineral.

Tabel 3 Jadwal pemberian pakan (Feeding schedule)

\begin{tabular}{|c|c|c|}
\hline \multirow[b]{2}{*}{ No } & & Harike- \\
\hline & 0 Jenis Pakan & $\begin{array}{lllllllllllllllllllllllllllll}12 & 3 & 4 & 5 & 6 & 7 & 8 & 9 & 10 & 11 & 12 & 13 & 14 & 15 & 16 & 17 & 18 & 19 & 20 & 21 & 22 & 23 & 24 & 25 & 26 & 27 & 28 & 29 & 30\end{array}$ \\
\hline 1 & Yolk egg & \\
\hline 2 & Kuning telur & \\
\hline 3 & Peletfenglio & \\
\hline
\end{tabular}

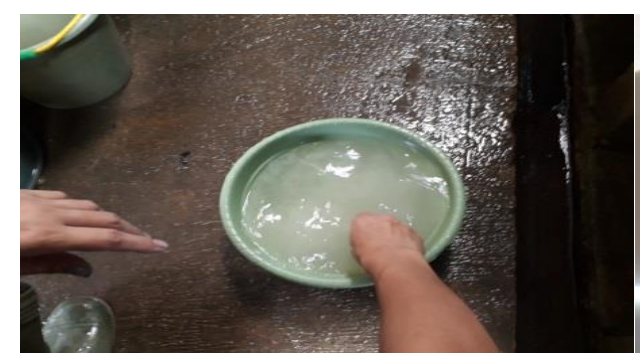

(a)

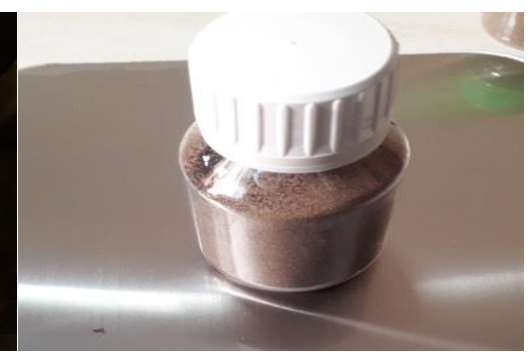

(b)

Gambar 11 Pakan Larva ikan lemon algae eater: (a) Kuning telur yang sudah dilarutkan (b) Pemberian pakan pelet Feng $\mathrm{Li}$

\subsection{Pengelolaan Kualitas Air Pada Larva}

Pengelolaan kualitas air pada pemeliharaan larva dilakukan dua hari sekali yaitu dengan cara penyiponan dan pergantian air. Penyiponan dilakukan menggunakan selang sipon yang berukan 0,5 inch. Penyiponan berfungsi sebagai membuang sisa pakan dan feses ikan. Kemudian pergantian air dilakukan dengan 
cara air diganti $80 \%$ dari tinggi air dengan menggunakan pipa yang dibentuk seperti filter disatukan dengan selang ukuran 1 inch (Gambar 12).

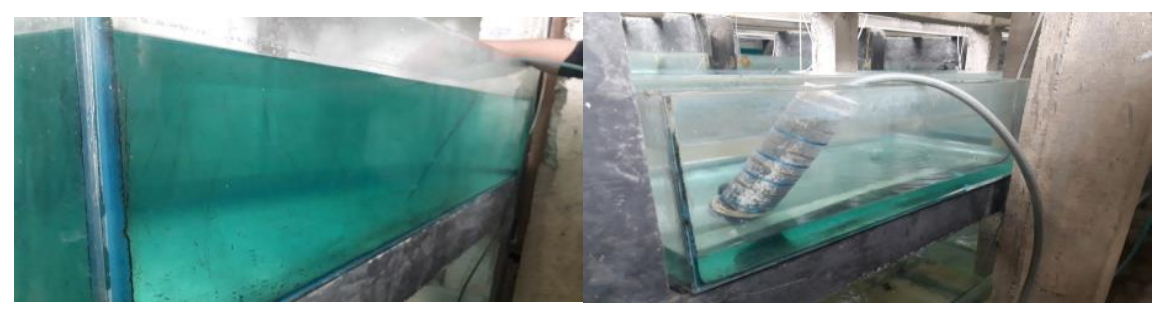

(a)

Gambar 12 Pengelolaan Kualitas Air Larva : (a) Penyiponan, (b) Pergantian air

\subsection{Pencegahan Hama dan Penyakit}

Pencegahan dan pemberantasan hama penyakit sangat penting dalam kegiatan budidaya, karena hama dan penyakit dapat mengganggu serta menghambat proses berjalannya kegiatan budidaya. Pada pemeliharaan larva ikan lemon algae eater terkadang menemui masalah, salah satunya terserang penyakit. Penyakit yang dapat menyerang larva ikan lemon algae eater adalah finrot. Penyakit finrot yang disebabkan oleh bakteri Flexibacter sp. yang memiliki ciri-ciri yaitu di bagian sirip mengalami pembusukan, tidak nafsu makan, dan sulit untuk berenang. Cara penanggulangan untuk mengatasi penyakit finrot yaitu pemberian obat furazolidone dengan dosis $2 \mathrm{~mL} / \mathrm{L}$ dan pergantian air sebanyak $50 \%$ dari tinggi air yang dilakukan 2 hari sekali (Gambar 13).

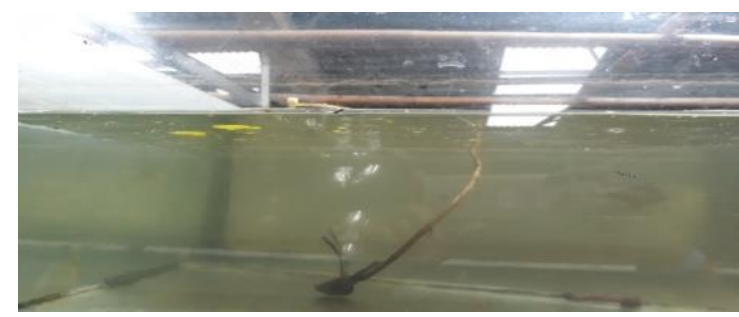

Gambar 13 Pengobatan menggunakan obat furazolidone

\section{Kegiatan Pendederan}

\subsection{Persiapan Wadah Benih}

Wadah untuk memelihara benih ikan lemon algae eater menggunakan bak beton yang berukuran $3 \mathrm{~m} \times 2 \mathrm{~m} \times 1.5 \mathrm{~m}$. Persiapan wadah dilakukan dengan cara menggosok dinding bak beton menggunakan sikat (Gambar 14). Kemudian bak beton dikeringkan selama 30 menit dan diisi air dengan tinggi $1 \mathrm{~m}$ dan didiamkan selama 1 hari. 


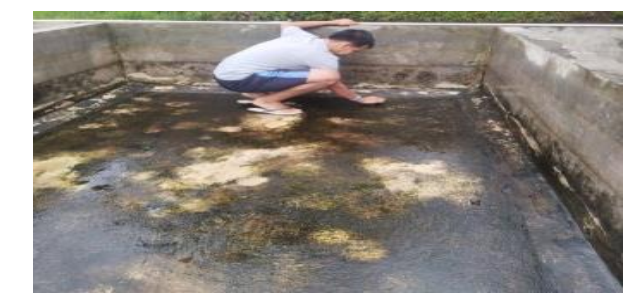

Gambar 14 Penggosokan wadah bak beton

\subsection{Penebaran Benih}

Benih yang ditebar merupakan benih dari hasil pembenihan di Ade's Fish Farm. Benih dengan umur 1 bulan berukuran 1,2-1,5 cm/ekor, dengan padat tebar 1 ekor/L. Dalam 1 wadah bak beton yang memiliki volume $6000 \mathrm{~L}$ dapat menampung 6000 ekor benih ikan lemon algae eater. Data hasil kegiatan pendederan ikan lemon algae eater dapat dilihat pada Tabel 4.

Tabel 4 Jumlah benih yang dipanen dan nilai tingkat kelangsungan hidup (SR)

\begin{tabular}{crrrr}
\hline Pemijahan ke- & Tanggal & $\begin{array}{c}\text { Jumlah benih } \\
\text { yang ditebar }\end{array}$ & $\begin{array}{r}\text { SR } \\
(\%)\end{array}$ & $\begin{array}{r}\text { Jumlah benih } \\
\text { yang dipanen }\end{array}$ \\
\hline 1 & $14 / 2 / 2020$ & 6100 & 83 & 5063 \\
2 & $16 / 2 / 2020$ & 6000 & 82 & 4920 \\
3 & $28 / 2 / 2020$ & 6200 & 75 & 4650 \\
4 & $02 / 3 / 2020$ & 6000 & 78 & 4680 \\
\hline & Rata-rata & 6075 & 80 & 4828 \\
\hline
\end{tabular}

\subsection{Pemberian Pakan Benih}

Pemberian pakan benih yang diberikan untuk benih ikan lemon algae eater menggunakan pakan buatan berupa pelet $781-2$ yang sudah dicampurkan $500 \mathrm{~mL}$ air dan dibentuk menjadi pasta (Gambar 15). Metode pemberian pakan menggunakan metode at-satiation atau pemberian pakan dengan cara sekenyangnya. Pemberian pakan dilakukan sebanyak 2 kali sehari, pada pagi hari pada pukul 08.30, dan pada sore hari pada pukul 16.00 .

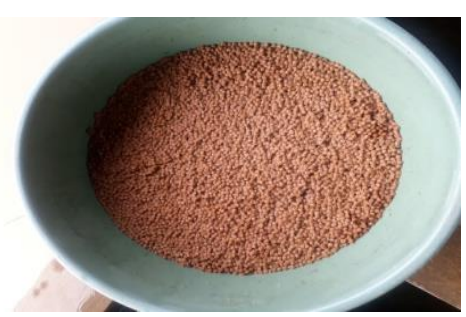

Gambar 15 Pelet $781-2$ yang dicampurkan $500 \mathrm{~mL}$ air

\subsection{Pengelolaan Kualitas Air Benih}

Pengelolaan kualitas air benih dilakukan tiga hari sekali dengan cara pergantian air sebanyak $50 \%$ dari tinggi air kemudian diisi kembali dengan tinggi air yang sama. Air yang digunakan adalah air sumur yang sudah diendapkan. Pergantian air berguna untuk membuang sisa-sisa pakan yang tidak dimakan dan 
hasil metabolisme ikan (feses). Monitoring kualitas air dilakukan dengan cara mengukur suhu dan $\mathrm{pH}$ sebanyak tiga kali sehari. Sedangkan pengukuran amonia dilakukan seminggu sekali (Gambar 16). Waktu pengukuran kualitas air yaitu pagi jam 07.00 WIB, siang jam 13.00 WIB, dan sore hari jam 16.00 WIB, pengukuran kualitas air diukur di bagian pertengahan kolam. Data hasil pengukuran kualitas air pada keseluruhan kolam induk ikan lemon algae eater dapat dilihat pada Tabel 5.

Tabel 5 Data Kualitas Air Benih Lemon Algae Eater

\begin{tabular}{cccc}
\hline Parameter & $\begin{array}{c}\text { Pengukuran } \\
\text { Kualitas air }\end{array}$ & $\begin{array}{c}\text { Kualitas air di alam } \\
\text { (Kusrini dan Priono 2011) }\end{array}$ & $\begin{array}{c}\text { Baku mutu untuk ikan } \\
\text { Arwana } \\
(\text { SNI 2011) }\end{array}$ \\
\hline Suhu & $27^{\circ} \mathrm{C}-30^{\circ} \mathrm{C}$ & $26{ }^{\circ} \mathrm{C}-31^{\circ} \mathrm{C}$ & $20^{\circ} \mathrm{C}-30^{\circ} \mathrm{C}$ \\
$\mathrm{pH}$ & $6,5-7$ & $5-6,5$ & $5-7$ \\
Amonia & $0,025 \mathrm{mg} / \mathrm{L}$ & Maksimal $1 \mathrm{mg} / \mathrm{L}$ & Maks 0,02 \\
\hline
\end{tabular}

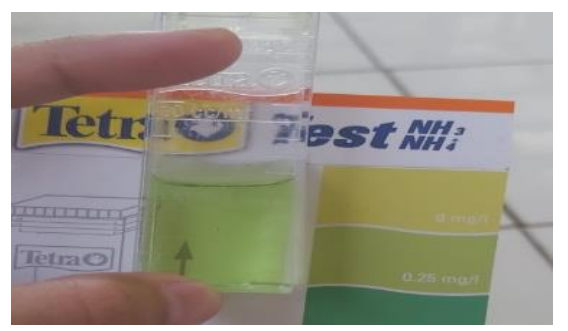

Gambar 16 Pengukuran amoniak

\subsection{Pencegahan dan Pemberantasan Hama Penyakit}

Dalam kegiatan budidaya, pencegahan dan pemberantasan hama penyakit sangat penting karena hama dan penyakit dapat mengganggu serta menghambat proses berjalannya kegiatan budidaya yang dapat merugikan usaha budidaya ikan lemon algae eater. Penyakit yang sering menyerang pada kegiatan benih ikan lemon algae eater yaitu finrot. Penyakit finrot disebabkan oleh bakteri Flexibacter sp. yang mempunyai ciri-ciri yaitu pembusukan pada bagian sirip ekor, nafsu makan rendah dan ikan sulit berenang.

Cara penanggulangan yang digunakan untuk mengatasi penyakit finrot yaitu pergantian air sebanyak $50 \%$ dari tinggi air yang dilakukan 2 hari sekali. Selain itu penanggulangan penyakit finrot dapat dilakukan dengan menambahkan garam akuarium sebanyak $0,03 \%$ atau merendam dengan furazon green dan menambahkan slim coat protector untuk melindungi slim coat (lapisan lendir pada ikan; https://daftarhewan.com)

\subsection{Penyortiran dan Pengurangan Padat Tebar Benih}

Benih yang sudah berumur 30 hari akan dilakukan penyortiran dan pengurangan padat tebar. Langkah awal yang dilakukan pada saat melakukan penyotiran dan pengurangan padat tebar yaitu, benih diserok dengan serokan besar ukuran $60 \mathrm{~cm} \times 50 \mathrm{~cm}$, kemudian benih yang akan disortir dibagi menjadi beberapa ukuran (ukuran 1,2-1,5 cm/ekor dan ukuran 2-2,5 cm/ekor). Setelah 
benih di sortir menjadi beberapa ukuran, benih di aklimatisasi terlebih dahulu kemudian ditebar. Benih ditebar dengan kepadatan 6000 ekor $/ \mathrm{m}^{2}$.

\subsection{Pemanenan dan Transportasi}

Pemanenan pada ikan lemon algae eater dilakukan setelah benih berumur 30 hari dengan ukuran panjang mencapai 1,2-1,5 cm/ekor untuk kegiatan pembenihan. Sedangkan untuk kegiatan pendederan, benih lemon algae eater dipelihara sampai umur 45 - 50 hari dengan ukuran panjang mencapai $2-2,5$ $\mathrm{cm} /$ ekor. Benih yang akan dipanen sebelumnya dilakukan perlakuan pemberokan selama 1 hari. Pemberokan bertujuan untuk mengurangi proses metabolisme ikan sehingga pada saat benih lemon algae eater didistribusikan tidak banyak mengeluarkan feses. Setelah dilakukan perlakuan pemberokan, ikan lemon algae eater diserok dari wadah bak beton dengan hati-hati agar ikan tidak mengalami stress dan luka (Gambar 17 a). Kemudian ikan lemon algae eater disortir dan dihitung jumlah sesuai dengan yang dipesan konsumen (Gambar 17 b). Ikan yang telah disortir, kemudian dimasukan kedalam plastik packing ukuran $40 \mathrm{~cm} \times 60 \mathrm{~cm}$ yang sudah dirangkap menjadi 2 plastik. Kepadatan benih setiap kantongnya berbeda-beda sesuai dengan ukurannya. Pada ukuran 1,5 cm/ekor kepadatan perkantongnya yaitu 500 ekor sedangkan ukuran 2,5 cm/ekor kepadatan perkantongnya 200 ekor. Cara yang digunakan saat proses packing yaitu menggunakan packing tertutup dengan perbandingan oksigen dan air 2:1.

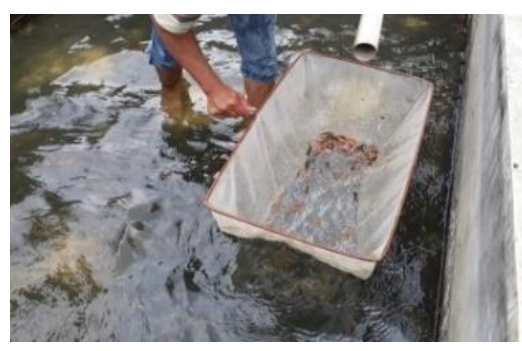

(a)

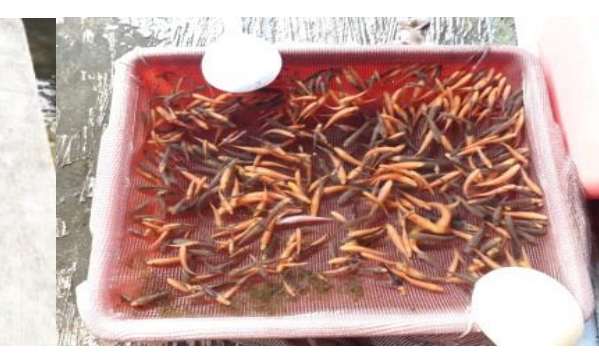

(b)

Gambar 17 Pemanenan Benih : (a) Penyerokan ikan, (b) Penyortiran ikan

\section{SIMPULAN}

Keseluruhan aspek teknis produksi pembenihan dan pendederan sudah baik karena memiliki nilai Survival Rate pada pembenihan dan pembesaran masingmasing sebesar $74 \%$ dan $80 \%$, yang tergolong tinggi. Proses produksi pembenihan dan pendederan terdiri atas pemijahan induk, penetasan telur, pemeliharaan larva, pemeliharaan benih, Rata-rata fekunditas telur ikan lemon algae eater yang dihasilkan dalam satu kali pemijahan mencapai 95.958 butir telur dengan memiliki nilai rata-rata derajad pembuahan (Fertilization Rate) sebesar $79 \%$, derajad penetasan (Hatching Rate) sebesar $83 \%$. Benih yang dipanen berumur 30 hari dan 45 hari dengan ukuran 1,2-1,5 cm/ekor dan 2,5 - $3 \mathrm{~cm} / \mathrm{ekor}$.

\section{SARAN}

Menertibkan kembali mengenai SOP kegiatan budidaya ikan agar hasil produksi semakin baik. Memperhatikan sumber air, saluran pembuangan tetap 
lancar agar proses produksi tidak terganggu, serta melakukan pembersihan dan mengusahakan sterilisasi alat-alat kegiatan budi daya setelah digunakan; dengan tujuan meminimalkan kontaminasi bakteri, virus sehingga ikan-ikan sehat, terhindar dari stres, dan tidak mudah sakit.

\section{DAFTAR PUSTAKA}

Amri K., Khairuman. 2002. Pengemasan (Packing) dalam Buku Budidaya Lele Secara Intensif. Agromedia Pustaka. Jakarta.

[DJPB] Direktorat Jenderal Perikanan Budidaya. 2021. Budidaya Ikan Hias Tingkatkan Pendapatan Masyarakat di Tengah Pandemi. Jakarta: Direktorat Jenderal Perikanan Budidaya Kementerian KeLautan dan Perikanan.

Fanitalya. 2012. Pengaruh Ekstrak Daun SirihTerhadap Infeksi Jamur Pada Telur Ikan Gurame (Osphronemus gouramy). Jurnal Perikanan Unram,Volume 1, No.1.

Fricke R., Eschmeyer W. N., Van der Laan, R. 2021. Eschmeyer's Catalog of Fishes: Genera Species References. (http://researcharchive.calacademy.org/research/ichthyology/catalog/fishcat main.asp). Electronic version accessed 070062021.

Khairuman. 2003. Menanggulangi Penyakit pada Larva Ikan Mas dan Koi. Penerbit Agro Media Pustaka, Jakarta.

KKP Pusat Data Statistik dan Informasi, Kemetrian Kelautan dan Perikanan. 2017. Kelautan dan Perikanan dalam Angka Tahun 2017.

Kottelat M. 2013. The Fishes of The Inland Waters of Southeast Asia : A Catalogue and Core Bibliography of The Fishes Known to Occur in Freshwaters, Mangroves and Estuaries. The Raffles Bulletin of Zoology Supplement. No. 27: 1-663

Kusrini E., Priono B. 2011. Pakan Buatan untuk Pengembangan Budidaya Ikan Discus (Symphysodon discus) di Indonesia. Jurnal Media Akuakultur. 6(1): 32-35.

Memis D., Gun, H. 2004. Effects of Different diets on The Growth Performance, Gonad Development and Body Composition at First Sexual Maturity of Rainbow Trout (Oncorhynchus mykiss). Turk J Vet Anim Sci., 28: 315-322

Nainggolan A. 2014. Peningkatan Mutu Reproduksi Induk Betina Lele (Clarias Sp.) melalui Pemberian Kombinasi Pakan Bersuplemen Spirulina Platensis dan Oodev [Skripsi]. Institut Pertanian Bogor. 106 hal

Oktariza W., Sukmawati A. 2017. Kebijakan Pengentasan Kemiskinan di Kawasan Perdesaan Melalui Usaha Budidaya Perikanan di Kabupaten Malang. Jurnal Sains Terapan. 7(1): 1-11

Penulis daftarhewan. 2019. Penyakit Ikan Mas Koki Busuk Sirip (Fin Rot). https://daftarhewan.com

[SNI] Standar Nasional Indonesia. 2011. Ikan Hias Arwana (Sceleropages formosus) Syarat Mutu dan Penanganan. SNI: 7736: 2011.

Suriansyah, Zairin, M.J., Sudrajat, A.O. 2010. Study of Gonadotrophin (GtH) Stimulating Hormone of Gonad Maturation of Climbing Perch Anabas testudineus Bloch. Jurnal Aquaculture Indonesia. Vol. 9 No 1 
Tang M.U., Affandi, R. 2000. Biologi Reproduksi Ikan. UNRI Press. Pekanbaru. Tarwiyah. 2001. Prospek Budi daya Ikan Hias Mas Koki. Dinas Perikanan DKI Jakarta.

Vidthayanon C. 2012. Gyrinocheilus aymonieri. The IUCN Red List of Threatened Species 2012:

e.T180997A1686747.

http://dx.doi.org/10.2305/IUCN.UK.2012-1.RLTS.T180997A1686747.en

Wijayanti G.E., Simanjuntak, S.B.I. 2006. Viabilitas Sperma Ikan Nilem (Osteochilus hesselti C.V.) Setelah Penyimpanan Jangka Pendek dalam Larutan Ringer. Jurnal Perikanan. 8(2): 207-214. 